\title{
Receptor guanylyl cyclase-G is a sensory protein activated by cool temperatures and predator odor 2,4,5-trimethylthiazoline
}

\author{
Ruey-Bing Yang ${ }^{1,2}$ \\ From 7th International Conference on cGMP Generators, Effectors and Therapeutic Implications \\ Trier, Germany. 19-21 June 2015
}

\section{Background}

Receptor guanylyl cyclase (GC)-G is highly expressed in neurons of the Grueneberg ganglion (GG) in the anterior region of the murine nose, whose cells are activated by cool temperatures and volatile danger cues such as alarm pheromones and other structurally similar semiochemicals involuntary released by predators $[1,2]$. The predator odor 2,4,5-trimethylthiazoline (TMT), a volatile scent originally isolated from fox feces, induces robust innate freezing behaviors in rodents [3]. To date, molecular identities of the GG sensors for cool temperatures and pheromones are largely unclear. In addition to GCG, GG neurons express signaling elements associated with cyclic guanosine monophosphate (cGMP), including the cGMP-stimulated phosphodiesterase $2 \mathrm{~A}$ and the cGMP-activated ion channel CNGA3 [4-6]. Interestingly, recent reports suggest that cGMP signaling is crucial for thermal transduction and odorant-evoked electrical responses in the GG neurons [6,7]. However, whether GC-G directly acts as a sensor for cool temperatures and/or predator odor TMT remain elusive.

\section{Materials and methods}

A combination of biochemical and molecular biology methods, $\mathrm{Ca} 2+$ imaging as well as behavioural studies comparing wild-type and GC-G-knockout (KO) mice was used to elucidate the molecular and biological function of GC-G in sensing cool temperatures and predator scent TMT.

\section{Results}

We show that GC-G is a dual thermosensory and pheromone receptor that can be maximally stimulated by cool temperatures of about $15^{\circ} \mathrm{C}$ and TMT in both in vivo cellular cGMP accumulation assays and in vitro $\mathrm{GC}$ assays. Mechanistically, while coolness enhances dimerization of GC-G, TMT directly binds the extracellular domain of GC-G to stimulate its enzymatic activity. Consistent with these findings, we observed substantially reduced coolness-induced responses of GG neurons and coolness-evoked ultrasonic vocalization in GC-G-KO pups. Likewise, TMT-induced calcium transients in the GG as well as TMT-evoked innate fear behaviors and an increase of serum corticosterone (a stress hormone) were markedly attenuated in the GC-G-KO mice compared to wild-type littermates.

\section{Conclusions}

Our data suggest that GC-G is a double functional receptor in the GG for sensing cool temperatures and predator scents in an age-specific manner. Whereas GC-G activation in the GG by coolness is critical for the generation of ultrasound calls by isolated pups to elicit maternal care [8], GC-G can detect the predator odor TMT to evoke innate defensive responses in adult mice to maximize species survival.

\section{Authors' details \\ ${ }^{1}$ Institute of Biomedical Sciences, Academia Sinica, Taipei, Taiwan. ${ }^{2}$ Institute of Pharmacology, School of Medicine, National Yang-Ming University, Taipei, Taiwan.}

Published: 2 September 2015 


\section{References}

1. Brechbuhl J, Klaey M, Broillet MC: Grueneberg ganglion cells mediate alarm pheromone detection in mice. Science 2008, 321:1092-1095.

2. Brechbuhl J, Moine F, Klaey M, Nenniger-Tosato M, Hurni N, Sporkert F, Giroud C, Broillet MC: Mouse alarm pheromone shares structural similarity with predator scents. Proc Natl Acad Sci USA 2013, 110:4762-4767.

3. Wallace KJ, Rosen JB: Predator odor as an unconditioned fear stimulus in rats: elicitation of freezing by trimethylthiazoline, a component of fox feces. Behav Neurosci 2000, 114:912-922.

4. Fleischer J, Mamasuew K, Breer H: Expression of cGMP signaling elements in the Grueneberg ganglion. Histochem Cell Biol 2009, 131:75-88.

5. Liu CY, Fraser SE, Koos DS: Grueneberg ganglion olfactory subsystem employs a cGMP signaling pathway. J Comp Neurol 2009, 516:36-48.

6. Mamasuew K, Michalakis S, Breer H, Biel M, Fleischer J: The cyclic nucleotidegated ion channel CNGA3 contributes to coolness-induced responses of Grueneberg ganglion neurons. Cell Mol Life Sci 2010, 67:1859-1869.

7. Hanke W, Mamasuew K, Biel M, Yang RB, Fleischer J: Odorant-evoked electrical responses in Grueneberg ganglion neurons rely on cGMPassociated signaling proteins. Neurosci Lett 2013, 539:38-42.

8. Chao YC, Chen CC, Lin YC, Breer H, Fleischer J, Yang RB: Receptor guanylyl cyclase- $G$ is a novel thermosensory protein activated by cool temperatures. EMBO J 2015, 34:294-306.

doi:10.1186/2050-6511-16-S1-A29

Cite this article as: Yang: Receptor guanylyl cyclase-G is a sensory protein activated by cool temperatures and predator odor 2,4,5trimethylthiazoline. BMC Pharmacology and Toxicology 2015 16(Suppl 1): A29.

\section{Submit your next manuscript to BioMed Central} and take full advantage of:

- Convenient online submission

- Thorough peer review

- No space constraints or color figure charges

- Immediate publication on acceptance

- Inclusion in PubMed, CAS, Scopus and Google Scholar

- Research which is freely available for redistribution

Submit your manuscript at www.biomedcentral.com/submit 